\title{
Quality of life and prevalence of osteoarticular pain in patients submitted to bariatric surgery
}

\author{
Qualidade de vida e prevalência de dor osteoarticular em \\ pacientes submetidos à cirurgia bariátrica
}

\author{
Rute Grans ${ }^{1}$, Cyntia Francesca Warth ${ }^{2}$, José Francisco de Mattos Farah², Debora Pastore Bassitt ${ }^{2}$
}

\begin{abstract}
Objective: To analyze quality of life and observe the prevalence of musculoskeletal pain in patients submitted to bariatric surgery. Methods: A prospective, observational and comparative study with 26 individuals aged 18 to 60 years, 25 women, which included two evaluations, one preoperative and the other approximately 42 months after surgery. The Medical Outcomes Study 36-Item Short Form Health Survey (SF-36) and the Human Body Diagram with Visual Analogue Scale were employed. Results: The individual samples showed grade III obesity, with a predominance of postoperative overweight, hypertension and diabetes in $65.4 \%$ and $42.3 \%$ of the samples, with remission of hypertension in $50 \%$ and of diabetes mellitus in $38.5 \%(p<0.001)$. The SF-36 demonstrated improved quality of life, especially in aspects related to motricity; vitality and mental health showed no significant changes. Osteoarticular pain was reported and identified in various sites by the subjects; however, $87.5 \%$ of patients in the preoperative period and $88.5 \%$ in the postoperative period reported not having any physical therapy orientation, while $65.4 \%$ reported being engaged in some type of regular physical activity after surgery $(p<0.001)$. Conclusion: Morbidly obese individuals have a high probability of suffering from clinical, psychic, and musculoskeletal alterations, compromising their quality of life and showing improvement after bariatric surgery; on the other hand, the psycho-emotional manifestations did not progress in the same way.
\end{abstract}

Keywords: Pain, postoperative/etiology; Arthralgia/etiology; Obesity; Bariatric surgery; Quality of life

\section{RESUMO}

Objetivo: Analisar a qualidade de vida e observar a prevalência de dor musculoesquelética em pacientes submetidos à cirurgia bariátrica.
Métodos: Estudo prospectivo, observacional e comparativo, incluindo 26 amostras, idade entre 18 e 60 anos, sendo 25 mulheres e compreendendo duas avaliações, uma pré-operatória e outra cerca de 42 meses após a cirurgia, com aplicação do Medical Outcomes Study 36-Item Short Form Health Survey (SF-36) e do Diagrama do Corpo Humano com Escala Visual Analógica. Resultado: As amostras apresentaram obesidade grau III, com predomínio de sobrepeso após cirurgia, hipertensão e diabetes presentes em $65,4 \%$ e $42,3 \%$ das amostras, com remissão da hipertensão em $50 \%$ e da diabete mellitus em $38,5 \%(p<0,001)$. 0 SF-36 evidenciou melhora da qualidade de vida, sobretudo nos aspectos relacionados à motricidade; vitalidade e saúde mental não apresentaram mudanças significativas. A dor osteoarticular esteve presente e foi apontada em diversos pontos pelos sujeitos da amostra; contudo, 87,5\% dos pacientes no pré e $88,5 \%$ no pós-operatório relataram não ter realizado nenhum acompanhamento fisioterápico, enquanto $65,4 \%$ relataram fazer algum tipo de atividade física regularmente após a cirurgia $(p<0,001)$. Conclusão: Obesos mórbidos apresentam alta probabilidade de sofrer com as alterações clínicas, psíquicas e musculoesqueléticas, comprometendo sua qualidade de vida e apresentando melhora após a cirurgia bariátrica; por outro lado, as manifestações psicoemocionais não tiveram a mesma evolução.

Descritores: Dor pós-operatória/etiologia; Artralgia/etiologia; Obesidade; Cirurgia bariátrica/complicações; Qualidade de vida

\section{INTRODUCTION}

Since the 1990s, interest in the contributing factors of obesity has increased and lack of physical exercise, food ingestion and behavior patterns are observed as elements of risk for the population ${ }^{(1)}$.

Study carried out at Instituto de Assistência Médica ao Servidor Público Estadual - IAMSPE, São Paulo (SP), Brazil.

${ }^{1}$ Graduate Program (Master's degree), Instituto de Assistência Médica ao Servidor Público Estadual - IAMSPE, São Paulo (SP), Brazil.

2 Hospital do Servidor Público Estadual "Francisco Morato de Oliveira" - HSPE-FMO, São Paulo (SP), Brazil.

Corresponding author: Rute Grans - Rua das Vertentes, 584 - Tucuruvi - Zip code: 022560-000 - São Paulo (SP), Brazil - Phone: (55 11) 5088-8428 - E-mail: rutegrans@gmail.com

Received on: May 11, 2012 - Accepted on: Nov 5, 2012

Conflict of interest: none. 
Obesity is considered a chronic non-communicable disease and worldwide epidemics, causing approximately 2.5 million deaths a year ${ }^{(2)}$. It is estimated that in Brazil there are about 10.5 million obese individuals ${ }^{(3)}$.

Obesity is associated with the most severe and morbid clinical, postural, and musculoskeletal conditions, among others, contributing to reduced quality and expectancy of life. Among co-morbidities, the degenerative joint diseases stand out because of acute and chronic pain, discouraging physical activity and negatively influencing the emotional state ${ }^{(4,5)}$.

Musculoskeletal alterations are responsible for the second amount of total expenditures with obese patients, and are surpassed only by cardiovascular complications $\mathbf{s}^{(6)}$. The relation with obesity results from osteoarticular alterations caused by excessive body mass, reduced stability, and increased mechanical needs for corporal adjustment $^{(7)}$, and the main postural alterations derive from pro-equilibrium compensation ${ }^{(7-9)}$. There is an overburden on the vertebral spine and lower limbs, leading to arthritis of the joints in the spine, hips, knees, and ankles ${ }^{(6,9)}$.

Chronic pain is the primary cause of suffering, incapacitation for work, and severe psychosocial and economic disorders, compromising quality of life ${ }^{(8)}$.

In face of this troublesome scenario, currently the number of bariatric operations is constantly increasing ${ }^{(10)}$. The scope of bariatric surgery includes reduction of co-morbidities and improved quality of life, and not merely weight reduction. Weight loss per se is not a predictor of improved quality of life; it is linked to a set of factors associated with changes in lifestyle that lead to improvement of osteoarticular problems ${ }^{(11)}$.

\section{OBJECTIVE}

To analyze quality of life and prevalence of musculoskeletal pain, physical and functional capacity of the group during each stage, based on pre- and postoperative data regarding bariatric surgery.

\section{METHODS}

A prospective, observational, and comparative study was performed, with the use of informed consent. Twenty-six patients, aged between 18 and 60 years ( 25 females) were enrolled, with mean initial age of 44.8 years and mean final age of 48.3 years. The study included a preoperative evaluation and another about 42 months after surgery, with monitoring of clinical charts, application of the Medical Outcomes Study 36-Item Short Form Health Survey (SF-36) questionnaire and of the Human Body Diagram with Visual Analogue Scale (VAS), with both numerical and facial scales, for analysis of musculoskeletal pain. Non-parametric and linear regression statistical tests were applied, with $\mathrm{p}<0.05$ and the use of Statistical Package for Social Sciences (SPSS) V16, Minitab 15, and Excel Office 2007 software.

\section{RESULTS}

The mean weight measured was $128 \mathrm{~kg}$ in the preoperative phase and $82 \mathrm{~kg}$ in the postoperative phase $( \pm 13.2 \mathrm{~kg})$. The body mass index (BMI) before surgery was 49.2 and postoperatively, 32 ( \pm 5.3 in both, with $\mathrm{p}<0.001)$. Grade III obesity was present in $96.2 \%$, maintained at $11.5 \%$ after surgery $(\mathrm{p}<0.001) ; 38.5 \%$ were overweight $(\mathrm{p}<0.001)$.

Psychiatric disturbances (depression, suicidal thoughts, and desire to die) under treatment and use of medication were identified in $34.6 \%$ of the sample during the first phase and in $11.5 \%$ during the second $(\mathrm{p}=0.048)$.

Hypertension occurred in the first phase in $65.4 \%$ of the sample and in $11.5 \%$ during the second phase. Diabetes was initially present in $42.3 \%$, in contrast with $3.8 \%$ after surgery ( $<<0.001$ for both).

Results of the SF-36 in the pre- and postoperative correlation showed significance in functional capacity (36.5-85.6), physical aspect (27.9-84.6), and pain (45.377.1 ), all with $\mathrm{p}<0.001$. For the general health status (43.6-53.8), and social aspect (45.2-58.7), both with $\mathrm{p}=0.002$, and emotional aspect with (37.2-75.6), with $\mathrm{p}=0.005$. For vitality (VT), which was 51.7 at both time points, and mental health (MH, 53.4-54.8), there were no statistically relevant results (Table 1).

As to quantification of pain with the VAS, there was intense pain the knees in $42.3 \%$ of patients on the left (L) and $30.8 \%$ on the right (R), and moderate pain in $23.1 \%$ for both joints during the first phase. During the second phase, the results were $3.8 \%$ on the left side and $7.7 \%$ on the right for intense pain, and $23.1 \%$ (left) and $11.5 \%$ (right) for moderate pain, with $\mathrm{p}<0.001$ for intense pain (left) and $\mathrm{p}=0.035$ (right), respectively, at the two time points (Table 2).

Low back pain was intense in $30.8 \%$ on the right side of the body and in $26.9 \%$ on the left, in the preoperative phase, and was reduced to $0.0 \%$ in both sides.

In the hips initially there was $15.4 \%$ of intense pain on both sides, with a reduction to $0.0 \%$ on the right side $(p=0.037)$ and to $7.7 \%$ on the left. During the postoperative phase, the values were $3.8 \%$ for moderate pain on the left side, and $7.7 \%$ on the right.

For the ankles, before surgery, there was intense pain in $26.9 \%$ on the right and $30.8 \%$ on the left, which was reduced to $0.0 \%$ on both sides postoperatively $(p=0.004$ for the right and $p=0.002$ for the left) (Table 3$)$. 
Table 1. Analysis of comparison of SF-36 questionnaire results in the pre- and postoperative periods

\begin{tabular}{|c|c|c|c|c|c|c|c|c|c|}
\hline SF-36 & & Mean & Median & $\begin{array}{l}\text { Standard } \\
\text { deviation }\end{array}$ & $\begin{array}{c}1^{0} . \\
\text { Quartile }\end{array}$ & $\begin{array}{c}3^{\circ} . \\
\text { Quartile }\end{array}$ & $\mathbf{n}$ & Cl & p value \\
\hline \multirow[t]{2}{*}{ Functional capacity } & Preop & 36.5 & 32.5 & 23.9 & 20.0 & 45.0 & 26 & 9.2 & \multirow{2}{*}{$<0.001$} \\
\hline & Postop & 85.6 & 92.5 & 18.3 & 80.0 & 100.0 & 26 & 7.0 & \\
\hline \multirow[t]{2}{*}{ Physical aspect } & Preop & 27.9 & 0.0 & 42.6 & 0.0 & 50.0 & 26 & 16.4 & \multirow{2}{*}{$<0.001$} \\
\hline & Postop & 84.6 & 100.0 & 39.4 & 100.0 & 100.0 & 26 & 15.2 & \\
\hline \multirow[t]{2}{*}{ Pain } & Preop & 45.3 & 41.0 & 22.9 & 31.0 & 51.8 & 26 & 8.8 & \multirow{2}{*}{$<0.001$} \\
\hline & Postop & 77.1 & 92.0 & 28.3 & 62.0 & 100.0 & 26 & 10.9 & \\
\hline \multirow[t]{2}{*}{ General status } & Preop & 43.6 & 40.8 & 14.2 & 35.0 & 52.0 & 26 & 5.4 & \multirow{2}{*}{0.002} \\
\hline & Postop & 53.8 & 52.0 & 11.8 & 45.5 & 57.0 & 26 & 4.5 & \\
\hline \multirow[t]{2}{*}{ Vitality } & Preop & 51.7 & 55.0 & 12.6 & 45.0 & 60.0 & 26 & 4.8 & \multirow{2}{*}{0.875} \\
\hline & Postop & 51.7 & 55.0 & 13.0 & 50.0 & 58.8 & 26 & 5.0 & \\
\hline \multirow[t]{2}{*}{ Social aspect } & Preop & 45.2 & 50.0 & 18.4 & 25.0 & 50.0 & 26 & 7.1 & \multirow{2}{*}{0.002} \\
\hline & Postop & 58.7 & 62.5 & 15.3 & 50.0 & 62.5 & 26 & 5.9 & \\
\hline \multirow[t]{2}{*}{ Emotional aspect } & Preop & 37.2 & 16.7 & 42.5 & 0.0 & 66.7 & 26 & 16.3 & \multirow{2}{*}{0.005} \\
\hline & Postop & 75.6 & 100.0 & 45.8 & 100.0 & 100.0 & 26 & 17.6 & \\
\hline \multirow[t]{2}{*}{ Mental health } & Preop & 53.4 & 56.0 & 14.8 & 52.0 & 60.0 & 26 & 5.7 & \multirow{2}{*}{0.482} \\
\hline & Postop & 54.8 & 56.0 & 15.2 & 56.0 & 60.0 & 26 & 5.8 & \\
\hline
\end{tabular}

Cl: confidence interval.

Table 2. Comparison between pre- and postoperative periods in distribution of the Visual Analogue Scale for pain in the knees

\begin{tabular}{|c|c|c|c|c|c|c|}
\hline \multirow{2}{*}{ Knee } & & \multicolumn{2}{|c|}{ Preoperative } & \multicolumn{2}{|c|}{ Postoperative } & \multirow{2}{*}{ p value } \\
\hline & & $\mathbf{n}$ & $\%$ & $\mathbf{n}$ & $\%$ & \\
\hline \multirow[t]{3}{*}{ R } & Mild & 0 & 0.0 & 1 & 3.8 & 0.313 \\
\hline & Moderate & 6 & 23.1 & 3 & 11.5 & 0.271 \\
\hline & Severe & 8 & 30.8 & 2 & 7.7 & 0.035 \\
\hline \multirow[t]{3}{*}{ L } & Mild & 0 & 0.0 & 0 & 0.0 & - \\
\hline & Moderate & 6 & 23.1 & 6 & 23.1 & 1.000 \\
\hline & Severe & 11 & 42.3 & 1 & 3.8 & $<0.001$ \\
\hline
\end{tabular}

R: right; L: left.

Table 3. Comparison between pre- and postoperative periods in distribution of the Visual Analogue Scale for pain in the ankle

\begin{tabular}{|c|c|c|c|c|c|c|}
\hline \multirow{2}{*}{\multicolumn{2}{|c|}{ Ankle }} & \multicolumn{2}{|c|}{ Preoperative } & \multicolumn{2}{|c|}{ Postoperative } & \multirow{3}{*}{$\begin{array}{c}\text { p value } \\
-\end{array}$} \\
\hline & & \multirow{2}{*}{$\begin{array}{l}\mathbf{n} \\
0\end{array}$} & \multirow{2}{*}{$\begin{array}{c}\% \\
0.0\end{array}$} & \multirow{2}{*}{$\begin{array}{l}\mathbf{n} \\
0\end{array}$} & \multirow{2}{*}{$\begin{array}{c}\% \\
0.0\end{array}$} & \\
\hline$R$ & Mild & & & & & \\
\hline & Moderate & 3 & 11.5 & 1 & 3.8 & 0.298 \\
\hline & Severe & 7 & 26.9 & 0 & 0.0 & 0.004 \\
\hline \multirow[t]{3}{*}{ L } & Mild & 0 & 0.0 & 0 & 0.0 & - \\
\hline & Moderate & 3 & 11.5 & 2 & 7.7 & 0.638 \\
\hline & Severe & 8 & 30.8 & 0 & 0.0 & 0.002 \\
\hline
\end{tabular}

R: right; L: left.

In the shoulder joint, during the preoperative period, there was moderate pain on both sides, with $23.1 \%$ on the right and $26.95 \%$ on the left. The percentage after surgery was maintained in the right shoulder and dropped to $15.4 \%$ on the left (Table 4).
Table 4. Comparison between pre- and postoperative periods in distribution of the Visual Analogue Scale for pain in the shoulder

\begin{tabular}{|c|c|c|c|c|c|c|}
\hline \multirow{2}{*}{\multicolumn{2}{|c|}{ Shoulder }} & \multicolumn{2}{|c|}{ Preoperative } & \multicolumn{2}{|c|}{ Postoperative } & \multirow{3}{*}{\begin{tabular}{|c} 
p value \\
0.313
\end{tabular}} \\
\hline & & \multirow{2}{*}{$\begin{array}{l}\mathbf{n} \\
1\end{array}$} & \multirow{2}{*}{$\begin{array}{c}\% \\
3.8\end{array}$} & \multirow{2}{*}{$\begin{array}{l}\mathbf{n} \\
0\end{array}$} & \multirow{2}{*}{$\begin{array}{c}\% \\
0.0\end{array}$} & \\
\hline R & Mild & & & & & \\
\hline & Moderate & 6 & 23.1 & 6 & 23.1 & 1.000 \\
\hline & Severe & 2 & 7.7 & 0 & 0.0 & 0.149 \\
\hline \multirow[t]{3}{*}{$\mathrm{L}$} & Mild & 1 & 3.8 & 1 & 3.8 & 1.000 \\
\hline & Moderate & 7 & 26.9 & 4 & 15.4 & 0.308 \\
\hline & Severe & 2 & 7.7 & 0 & 0.0 & 0.149 \\
\hline
\end{tabular}

On the Human Body Diagram, there was a difference between pre- and postoperative reports, with a greater incidence of pain in the knees: $53.8 \%$ for the right and $69.2 \%$ for the left, compared to $23.1 \%$ in both knees after surgery $(\mathrm{p}<0.001)$. Next came low back pain with $50 \%$ (right) and $53.8 \%$ (left) preoperatively, reduced to $15.4 \%$ on both sides postoperatively ( $\mathrm{p}$ value for the right $=0.008 ; \mathrm{p}$ value for the left $=0.004)$. Ankles showed $38.5 \%$ for the right and $42.3 \%$ for the left for complaints and a drop to $3.8 \%$ after surgery ( $\mathrm{p}$ value for the right $=0.002 ; p$ value for the left $<0.001$ ). Pain was recorded in the hip joint with $38.5 \%$ on both sides of the body before surgery, with a reduction of $7.7 \%$ for the right side $(p=0.008)$ and $11.5 \%$ for the left $(p=0.048)$. The shoulder joint was shown to be the most important point for complaints of pain, with $34.6 \%$ on the right and $38.5 \%$ on the left, but it continued at $23.1 \%$ on the right and $19.2 \%$ on the left (Table 5). 
Tabela 5. Comparison between pre- and postoperative periods in distribution of the Human Body Diagram for joint pain

\begin{tabular}{|c|c|c|c|c|c|c|}
\hline \multirow{2}{*}{ With pain } & & \multicolumn{2}{|c|}{ Preoperative } & \multicolumn{2}{|c|}{ Postoperative } & \multirow{2}{*}{ p value } \\
\hline & & $\mathbf{n}$ & $\%$ & $\mathbf{n}$ & $\%$ & \\
\hline \multirow{2}{*}{ Neck } & R & 8 & 30.8 & 4 & 15.4 & 0.188 \\
\hline & L & 8 & 30.8 & 4 & 15.4 & 0.188 \\
\hline \multirow{2}{*}{ Lumbar } & R & 13 & 50.0 & 4 & 15.4 & 0.008 \\
\hline & L & 14 & 53.8 & 4 & 15.4 & 0.004 \\
\hline \multirow{2}{*}{ Sacral } & R & 8 & 30.8 & 3 & 11.5 & 0.090 \\
\hline & L & 8 & 30.8 & 4 & 15.4 & 0.188 \\
\hline \multirow{2}{*}{ Ankle } & R & 10 & 38.5 & 1 & 3.8 & 0.002 \\
\hline & L & 11 & 42.3 & 1 & 3.8 & $<0.001$ \\
\hline \multirow{2}{*}{ Shoulder } & R & 9 & 34.6 & 6 & 23.1 & 0.358 \\
\hline & L & 10 & 38.5 & 5 & 19.2 & 0.126 \\
\hline \multirow{2}{*}{ Hip } & R & 10 & 38.5 & 2 & 7.7 & 0.008 \\
\hline & L & 9 & 34.6 & 3 & 11.5 & 0.048 \\
\hline \multirow{2}{*}{ Knee } & R & 14 & 53.8 & 6 & 23.1 & 0.023 \\
\hline & L & 18 & 69.2 & 6 & 23.1 & $<0.001$ \\
\hline
\end{tabular}

R: right; L: left.

Similar results were observed in the cervical and sacral segments, with intense or moderate pain on both sides in $15.4 \%$ and a drop to $7.7 \%$ on both sides postoperatively. A reduction to $0.0 \%(\mathrm{p}=0.037)$ was seen for intense pain in the sacral segment for the right and left sides, and for moderate pain to $7.7 \%$ for the right and to $11.5 \%$ for the left.

Nevertheless, despite complaints of pain, $87.5 \%$ of the samples before and $88.5 \%$ after surgery reported not having been submitted to any physical therapy orientations; $65.4 \%$ reported engaging in some type of regular physical activity after surgery, compared with $13.3 \%$ in the preoperative phase $(\mathrm{p}<0.001)$.

Linear regression analysis was applied, observing the relation between weight-associated low back pain $(\mathrm{p}<0.033$ initially), strongly influenced by the mental health aspect $\left(\mathrm{p}<0.023\right.$ initial and $\mathrm{p}<0.028$ final), with $\mathrm{R}^{2}$ for the initial model of $61.6 \%$ and 36.0 in the final model.

\section{DISCUSSION}

Studies such as that performed by Ferreira showed that the occurrence of emotional disorders in people with severe obesity problems is high, with depression, anxiety, and compulsive eating as the most frequent ${ }^{(12)}$. About $70 \%$ of the samples studied by Marchesini ${ }^{(13)}$ during the pre- and post-gastroplasty phases showed some kind of alteration related to mental health.

According to Gigante et al. ${ }^{(14)}$, the obese individuals showed a $2.5 \%$ risk of developing systemic arterial hypertension (SAH) compared to those who had normal weight. They are also at risk of developing diabetes, with a 20 -fold increase for BMI between 30 and $34.9 \mathrm{~kg} / \mathrm{m}^{2}$ and 38 -fold for BMI $>35 \mathrm{~kg} / \mathrm{m}^{2(15)}$.

According to other authors, the correlation between the two time points gives a better idea as to how obese patients see life and its repercussions after weight reduction. The results obtained by the SF-36 showed improvement in quality of life, especially in motricity, similar to the data from the studies by Dixon et al. ${ }^{(16)}$; this is also comparable to the data observed for factors VT and MH, which showed results of 33.4 to 54.4 in VT and 58.8 to 67 in $\mathrm{MH}$. Despite the differences found in this study and the comparison with literature, the values are still not very expressive, proving that the compromise of vitality and mental health did not show significant alterations, even with loss of weight.

In line with Yeng et al. ${ }^{(8)}$, the interpretation of pain involves various aspects related to sensitive, cognitive, behavioral and cultural conformations, with a clear influence of socioeconomic factors, family dynamics, and coping strategies and thoughts, which makes pain inherent to each individual with their personal history and life experience.

Studies located pain primarily in the lower limbs due to the mechanical stress and overload suffered by the local bones and joint structures ${ }^{(6,15)}$.

Marks $^{(17)}$ accompanied 100 patients with history of uni- and bilateral preoperative osteoarthritis. Of these, $75 \%$ reported pain in the knees versus $44 \%$ after surgery, which are data consistent with the authors.

In the lower limbs, particularly the ankles, the connection between overweight and arthopathy and arthralgia was investigated. In a study performed by the American Orthopedic Foot and Ankle Society, it was noted that $40.8 \%$ of the participants reported not having suffered pain before gaining extra weight ${ }^{(18,19)}$.

Soccol et al. ${ }^{(20)}$ discovered the presence of ankle arthralgia with $46.51 \%$ of complaints in the preoperative phase, a value reduced to $6.97 \%$ postoperatively, which is consistent with the results found here.

A study carried out by Hooper et al. ${ }^{(21)}$ focused on determining the prevalence points of musculoskeletal pain in 48 obese patients before and after surgery, and observed 110 complaints of low back pain before and 69 after surgery.

Melissas et al. ${ }^{(22)}$ followed up 50 candidates for bariatric surgery. Twenty-nine patients reported preoperative low back pain in contrast with ten patients in postoperative phase. These studies confirmed the findings described in the cases indicated in this study suggesting that with weight reduction there is a drop in 
the overload due to the structural alterations suffered by this region resulting from obesity ${ }^{(6-9)}$.

Larsson $^{(23)}$ studied 43 patients involved in a diet intervention program in which 13 initially reported neck pain and 11 maintained their complaints after 64 weeks, despite a small drop in weight. Neck pain may be linked to soft tissue disturbances, regional joint immobility, structural abnormalities, joint degeneration, psychic stress, or traumas.

In this ample survey, no reports were found of studies that identified the site or intensity of pain in the sacral region.

According to Hitt et al. ${ }^{(24)}$, obese patients have greater probability of suffering from back pain as compared to those who are not obese, with 1470 -fold greater chances for grade I, 1993 for grade II, and 1505 for grade III.

The obese individuals show alteration and dislocation of the center of gravity with greater range of motion, primarily vertical, and an increased anterior pelvic inclination, leading to greater dislocation of their body area and accentuated body work, causing overload of the joints in the pelvic girdle and lower limbs during all phases of movement ${ }^{(7,9)}$. There is an increase in joint stress and in the factors by which pain and discomfort are produced during walking with both feet ${ }^{(25)}$.

Weight reduction favors ambulation and decreases this overload; such factors are suggestive for lessening postoperative complaints of pain in the hip joint.

Soccol et al. ${ }^{(20)}$ followed up 31 women in the preoperative phase and after gastroplasty by means of the 6-minute walking test and noted 13 preoperative complaints of hip pain and 7 after weight reduction. The authors also observed that patients without lower limb arthralgia walked more before surgery when compared to those who presented with pain, with no significant differences after the operation ${ }^{(26)}$.

Pain symptoms are the most eminent characteristic of hip osteoarthritis ${ }^{(24)}$. It is worth mentioning that this study did not have the objective of diagnosing osteoarthritis.

Bankoff et al. ${ }^{(26)}$ highlighted breast weight as a contributing factor for the scapular region to be affected. Considering that in the present study the sample was made up basically by women, this may be a factor when associated with the constant use and overload of this joint and increase of adipose tissue in the upper limbs, forcing it to distance from the trunk, and may explain the prevalence of pain in the right shoulder, which remained stable and with moderate intensity, even with reduction of weight.

Ipso facto, it is an indisputable fact that pain is not only linked to excess weight, but also to postural issues as well as the poor use of joints, always forced to maximal effort, with high medium- and long-term costs.
In the broad literature search, no consistent studies were found focused on mapping and quantifying pain pre- and postoperatively in obese bariatric patients. More in-depth studies would be necessary for this.

Greater levels of obesity favor the appearance of pain in various locations of the body. Imbalanced synergism, due to alterations in the musculoskeletal system, compromises most movements and modifies the points of strength, balance and action, leading to structural and functional changes ${ }^{(26)}$.

Despite the complaints of pain presented in the sample, only one small group had physical therapy treatment. Considering that the morbidly obese are highly compromised biomechanically, in order to correct this lack of harmony and realign the musculoskeletal structure, altered as a result of the increased overload on segments and the postural modifications, a global structural rearrangement is necessary.

This body work may be carried out by a physical therapy program appropriate for the needs of each individual and initiated before surgery. It is important that it be maintained after surgery, preparing the body for the numerous alterations and musculoskeletal and biomechanical modifications that the body will undergo during the new phase of weight loss and accommodation.

Fjeldstad et al. ${ }^{(27)}$ consider the physical therapy orientation necessary for training and reeducation appropriate for these individuals, bearing in mind the comorbidities and clinical complications that appear as well as the functional and postural consequences of obesity.

Some authors, such as Suerland et al.(28), defend the idea that follow-up by a multidisciplinary team is the gold standard for effective treatment and bariatric success in the morbidly obese.

Anandacoomarasamy et al. ${ }^{(29)}$ asserted that obesity is related to structural and functional limitations. Three weeks after implementation of the reduction and specific training of balance, the postural stability improves and there is a reduction in the risks of falling during activities.

Despite the considerable increase in physical activity after surgery, it is noted that many patients do not adhere to this benefit, which studies proved to be extremely important for loss and maintenance of weight. Besides directly affecting improvement of the physical capacity, it also is useful in the functional capacity and is related to psychosocial benefits ${ }^{(30)}$. Consequently, if it is not well directed and applied, there is a tendency to promote worsening or even to trigger future problems.

Hitt et al. ${ }^{(24)}$ utilized multiple regression analysis to determine the relation between the BMI and the origin and category of body pain, demonstrating that the increase of one point in the BMI can elevate by 0.16 the reference of body pain in the sites reported. 
In this study it was possible to observe the relation between low back pain and weight, which was strongly influenced by the mental health aspect. However, the relation between pre- and postoperative pain, regardless of weight reduction, demonstrated little relevance, emphasizing $\mathrm{MH}$ as the most important point of the sample. As to the relation with intensity of pain, this will be the object of another study.

\section{CONCLUSION}

Morbidly obese individuals showed a high probability of suffering from clinical, psychic, and musculoskeletal alterations that compromise their quality of life, and demonstrated improvement after bariatric surgery; on the other hand, psycho-emotional manifestations did not evolve in the same manner. Even without the structural compromise and pain presented, the participation of professionals specialized in treating these alterations is still not very significant, and compliance with physical activity is still low, discarding its benefits and implications. In spite of advances and of the research already performed, studies that effectively related obesity, pain, mental health, and the influence of bariatric surgery in these aspects are still necessary.

\section{ACKNOWLEDGMENTS}

To the collaborators in this study: Eda Grans, Magda Medeiros, Sandra Vequentini, Cleuza Melo, Doutora Cidia Vasconcelos, Carolina Nassif, Guilherme Melendez, Adorizio Bonadinan, Jimmy Adams, and César Pagani, and to the patients, who are the motive and the reason for this study.

\section{REFERENCES}

1. Markus A. Neurobiology of obesity. Nature Neurosci. 2005:8(5):551.

2. Organização Mundial da Saúde (OMS). Obesidade: prevenindo e controlando a epidemia global. São Paulo: Roca; 2004.

3. Instituto Brasileiro de Geografia e Estatística (IBGE). Ministério da Saúde. Obesidade: Brasil está no primeiro mundo da obesidade. Paraná: Redação 0 Estado do Paraná; 2004

4. Mancini MC. Obstáculos diagnósticos e desafios terapêuticos no paciente obeso. Arq Bras Endocrinol Metab. 2001;45(6):584-608.

5. Sinisgalli LA, Rodrigues HJ, Mair V. Cirurgia bariátrica. In: Sarmento GJ. Fisioterapia respiratória no paciente critico: rotinas clinicas. São Paulo: Manole; 2005.

6. Radominski SC. Obesidade e doenças músculo-esqueléticas. Rev Bras Reumatol. 1998:38(5)275-78.

7. Campos FS, Silva As, Anhesim GA. Alterações posturais e abordagem fisioterapêutica em crianças e adolescentes obesos. In: Fisberg $M$. Atualização em obesidade na infância e adolescência. 2a ed. revista e atual. São Paulo: Atheneu; 2005
8. Yeng LT, Jacobsen MT, Hsing WT, Romano MA. Curso de avaliação e tratamento multidisciplinar em dor crônica. São Paulo: Instituto de Ortopedia e Traumatologia/HC; 2004.

9. Bruschini S, Nery CA. Aspectos ortopédicos na infância e adolescência. In: Fisberg M. Obesidade na infância e adolescência. São Paulo: Fundo Editoria BYK; 1995

10. Segal A, Fandino J. Indicações e contra-indicações para realização das operações bariátricas. Rev Bras Psiquiatr. 2002;24(Supl III):68-72.

11. Ali MR, Maguire MB, Wolfe BM. Assesment of obesity - related comorbidities: a novel scheme for evaluating bariatric surgical patients. J Am Coll Surg. 2006:202(1):70-7.

12. Ferreira T. Comunicação UNIFESP. Transtornos emocionais são inimigos na luta contra obesidade [texto na Internet]. 2006 [citado 2012 Jul 5]. Disponível em: http://dgi.unifesp.br/sites/comunicacao/index.php?c=Noticia\&m =ler\&c od $=4990 \mathrm{e} 303$

13. Marchesini SD. Acompanhamento psicológico tardio em pacientes submetidos à cirurgia bariátrica. ABCD Arq Bras Cir. 2010;23(2):108-13.

14. Gigante DP, Barros FC, Cora LA, Olinto P, Olinto MT. Prevalência de obesidade em adultos e seus fatores de risco. Rev Saúde Pública. 1997:31(3):236-46.

15. Geloneze B, Pareja JC. Cirurgia bariátrica cura a síndrome metabólica? Arq Bras Endocrinol Metab. 2006;50(2):400-7

16. Dixon JB, Dixon ME, O'Brien PE. Quality of life after lap-band placement influence of time, weight loss, and comorbidities. Obes Res. 2001;9(11):713-21.

17. Marks R. Obesity profiles with knee osteoarthritis: correlation with pain disability, disease progression. Obesity. 2007;15(7):1867-74.

18. Medical Week News. Survey: obesity may lead to foot and ankle problems [serial on the Internet]. 2005 [cited 2012 Jul 5]; july. Available from: http:// www.medicalweek.org/news/070305.htm

19. Medical News Today. Survey suggests obesity may cause foot problems [article on the Internet]. 2005 [cited 2012 Jul 5]. Available from: http://www. medicalnewstoday.com/releases/27570.php

20. Soccol FB, Peruzzo SS, Mortari D, Scortegagna G, Sbruzzi G, Santos PC, et al. Prevalência de artralgia em indivíduos obesos no pré e pós-operatório tardio de cirurgia bariátrica. Sci Med, Porto Alegre. 2009;19(2):69-74.

21. Hooper MM, Stellato TA, Hallowell PT, Seitz BA, Moskowitz RW. Musculoskeletal findings in obese subjects before and after weight loss following bariatric surgery. Int J Obes (Lond). 2007;31 (1):114-20.

22. Melissas J, Kontakis G, Volakakis E, Tsepetis T, Alegakis A, Hadjipavlon A The effect of surgical weight reduction on functional status in morbidly obese patients with low back pain. Obes Surg. 2005;15(3):378-81.

23. Larsson UE. Influence of weight loss on pain, perceived disability and observed functional limitations in obese women. Int J Obes Relat Metab Disord. 2004:28(2):269-77.

24. Hitt HC, McMillen RC, Thornton-Neaves T, Koch K, Cosby AG. Comorbiality of obesity and pain in a general population: results from the Southern Pain Prevalence Study. J Pain. 2007;8(5):430-6.

25. Bozzo CM, Garcia FF, Quintana PP, Urrutia RO. Estudio de La distribucion De peso corporal sobre las extremidades inferiores em bipedestacion em sujetos sanos. Kinesiologia. 1993;35:11-5.

26. Bankoff AD, Zamai CA, Schimdt A, Ciol P, Barros DD. Estudo das alterações morfológicas do sistema locomotor: postura corporal x obesidade. Rev Educ Fis UEM. 2003;14(2):41-8.

27. Fjeldstad C, Fjeldstad AS, Acree LS, Nickel KJ, Gardner AW. The influence of obesity on falls an quality of life. Dyn Med. 2008;7:4.

28. Sauerland $S$, Angrisani L, Belachew M, Chevallier JM, Favretti F, Finer $N$, Fingerhut A, Garcia Caballero M, Guisado Macias JA, Mittermair R, Morino M, Msika S, Rubino F, Tacchino R, Weiner R, Neugebauer EA; European Association for Endoscopic Surgery. Obesity surgery: evidence-based guidelines of the European Association for Endoscopic Surgery (EAES). Surg Endosc. 2005:19:200-21. 
29. Anandacoomarasamy A, Caterson I, Sambrook P, Fransen M, March L. The impact of obesity on the musculoskeletal system. Int J Obes (Lond). 2008;32(2):211-22.

30. Josbeno DA. The relatioship between physical activity, physical function and psychosocial variables in individuals post-bariatric surgery [dissertation] Pittsburgh: University of Pittsburg; 2009. [cited 2012 Jul 5]. Available from: http://etd.library.pitt.edu/ETD/available/etd-042322009-101049/unrestricted/ JosbenoD Dissertation 2009 etd.pdf 